\title{
EWA KOS
}

\section{Forms of therapy of a child with selective mutism in the environment outside the family, embedded in a behavioral therapeutic approach}

\begin{abstract}
Ewa Kos, Forms of therapy of a child with selective mutism in the environment outside the family, embedded in a behavioral therapeutic approach. Interdisciplinary Contexts of Special Pedagogy, no. 31, Poznań 2020. Pp. 287-304. Adam Mickiewicz University Press. ISSN 2300-391X. e-ISSN 2658-283X. DOI: https:/ /doi.org/10.14746/ ikps.2020.31.13
\end{abstract}

The aim of this study is to present the forms of work and guidelines concerning the treatment of children with selective mutism in the light of the hypothesis that selective mutism should be perceived as an anxiety disorder that appears in childhood. On the basis of a thorough review of the literature, the Author discusses the forms of educational and therapeutic interaction that can be used in the treatment of children with selective mutism in accordance with the behavioural approach, and marginally with the psychodynamic approach.

KEY WORDS: Selective mutism, selective mutism therapy, children with selective mutism at school and kindergarten

\section{Introduction}

A disorder of the nature of selective mutism (SM) was first described in the $19^{\text {th }}$ century. Then, in 1877, Clifton Kussmaul, describing the case of a child who refuses to speak, called the disorder vol- 
untary aphasia (aphasia volentaria), thus emphasising the voluntary refusal to speak in certain situations. In the early 1930s the name of the disorder was changed to elective mutism. Both terms did not accurately reflect the specific nature of the disorder, as they emphasised the deliberate, elective or voluntary nature of the refusal to speak. In 1994, the described condition was described as selective mutism in DSM-IV. Selectivity refers here to selected situations in which the child cannot speak, and not, as suggested by the previous terms, to the intended refraining from speaking in certain situations. ${ }^{1}$

Selective mutism is a relatively rare $^{2}$ and quite complex anxiety disorder that usually affects children at preschool and early school age. The symptoms of selective mutism usually appear between the ages of three and six, and the diagnosis is made between the ages of five and eight, most often after the child starts school. ${ }^{3}$

SM is characterised by the fact that the child cannot speak in certain social situations (usually perceived as uncomfortable), despite the acquired and preserved ability to speak and demonstrating it in the family environment.

SM has been included in the latest Diagnostic and Statistical Manual of Mental Disorders (DSM-5) of the American Psychiatric

${ }^{1}$ P. Wong (2010), Selective Mutism: A Review of Etiology, Comorbidities, and Treatment, Psychiatry, 7(3), pp. 23-31.

2 It is worth mentioning that it is difficult to clearly define the scope of this problem in the population for many reasons. However, based on the epidemiological studies performed in Western Europe, the United States, and Israel it results that $\mathrm{SM}$ (it concerns its extreme form - the so-called severe mutism) is a disorder, wóhich is observed in the population with a prevalence of $0.03-0.76 \%$ (Kopp, Gillberg 1997, pp. 257-262 as cited in Bystrzanowska 2018, Ford, Sladeczeck, Carlson, Kratoch, Will 1998, Bergman, Piacentini McCracken 2002, Elizur, Perednik 2003, pp. 1451-1459 as cited in Bystrzanowska 2018) up to $1.9 \%$ in Finland (Kumpulainen et al. 1998, pp. 24-29 as cited in Bystrzanowska 2018). Such a wide range of data reflects, first of all, the lack of uniformity in establishing the diagnosis of SM, and the differentiation of the image of the disorder in different individuals.

3 W. Sharp, C. Sherman, M. Alan (2007), Selective Mutism and Anxiety: A review of the current conceptualization of the disorder, Journal of Anxiety Disorders, 21 , pp. 568-579. 
Association, in the category of anxiety disorders diagnosed in infancy, childhood or adolescence. The diagnostic criteria of SM according to DSM-5 are:

a) Observed failure to speak only in specific situations.

b) The disturbance interferes with educational achievement of the child.

c) The duration of the disturbance is at least 1 month.

d) Knowledge of the spoken language.

e) The disturbance is not better accounted for by a communication disorder such as stuttering or other speech impediments.

f) The failure to speak is not due to a lack of knowledge. ${ }^{4}$

In ICD-10, the currently valid International Statistical Classification of Diseases and Related Health Problems, the SM criteria are defined in a similar way:

a) Language expression and comprehension, as assessed on individually administered standardised tests are within the 2 standard deviation limit, for the child's age.

b) Demonstrable evidence of a consistent failure to speak occurs only in specific social situations, despite speaking in other situations.

c) Duration of selective mutism that exceeds 4 weeks (excluding the first month of the child's stay in the new educational environment).

d) Absence of a pervasive developmental disorder.

e) Absence of a lack of fluency in the language that is expected to be spoken in the situation. ${ }^{5}$

The literature indicates probable causes of SM, but the aetiology of this disorder has not been clearly identified and defined. ${ }^{6}$ Selec-

4 DSM-V, Diagnostic and Statistical Manual of Mental Disorders, 5th ed., American Psychiatric Association, 2013.

${ }^{5}$ ICD-10, International Statistical Classification of Diseases and Related Health Problems, 10 $10^{\text {th }}$ Revision, volume I, 2008.

${ }^{6}$ It is not the intention of the Author to discuss the causes of SM in detail in this study. It is worth mentioning, however, that in the literature, apart from the genetically conditioned anxiety component, numerous reasons for the activation of this disorder (including biological, genetic, sociocultural factors) are indicated. There- 
tive mutism, for various reasons (including small populations of research samples, low prevalence of the disorder), is not a frequently discussed issue in scientific, especially empirical, studies in Polish literature. Recently, however, studies covering this issue have appeared.7 They focus on the description of SM, indication of diagnostic criteria, and discussion of the difficulties of children with SM at the early stages of education. Based on a thorough review of the literature (both Polish and foreign), it can be noted that only a few studies and reports describe various and mostly uncontrolled methods of support and therapy for children with SM. They also usually do not contain observation-related information that could prove to be a valuable source of data.

In this text, options for reducing the symptoms of SM (only nonpharmacotherapeutic interventions), which focus on the anxiety component of this disorder will be discussed. In the further part of the study, the techniques of therapy within the behavioural approach will be presented.

\section{Selected factors contributing to overcoming the fear of speaking in the educational environment}

As mentioned, it can be concluded that the prevalence rate of $\mathrm{SM}$ in the population is quite low, but the impact of this difficulty

fore, the reasons can be explained, among others, from the point of view of the relationship between SM and social phobia, social anxiety, response to trauma, neurological and audiological deficits, from the perspective of family systems.

${ }_{7}$ Selected positions on selective mutism include Holka-Pokorska J., PirógBalcerzak A., Jarema M. (2018), The controversy around the diagnosis of selective mutism - a critical analysis of three cases in the light of modern research and diagnostic criteria, Psychiatria Polska, 52(2), pp. 323-343; Bystrzanowska M. (2018), Mutyzm wybiórczy. Poradnik dla nauczycieli i specjalistów, Impuls, Kraków; Bawolska A. (2019). Dziecko z mutyzmem wybiórczym - charakterystyka zjawiska oraz sposoby przeciwdziałania trudnościom. Niepełnosprawność - Dyskursy Pedagogiki Specjalnej, (33), pp. 204-212; Rozenek E., Orlof W., Nowicka Z. (2020), Opis zaburzenia i etiologia: czy wybiórczy brak mowy jest zaledwie wierzchołkiem góry lodowej?, Psychiatria Polska, 54(2), pp. 333-349. 
on the functioning of the individual is ubiquitous and may pose a serious threat to the mental health, social development, well-being of students in an educational institution (as a result of difficulties experienced by students with SM, they may show reduced effectiveness in achieving educational success, and problems in establishing relationships with peers, teachers). ${ }^{8}$

The disorder may be present for several months or persist for several years, although most SM symptoms tend to self-extinguish for unknown reasons. ${ }^{9}$ However, despite apparent remission, the activities associated with the necessity to speak are still carried out reluctantly by the individual, and isolation, social phobia, and other anxiety disorders may persist. ${ }^{10}$

For this reason, it is important that systematic educational, preventive and therapeutic interventions are undertaken at the earliest possible stage of child development. The results of the available studies indicate that children treated for SM at a younger age show faster progress in therapy than older children. These results were similar in a longer term. ${ }^{11,12}$

The effectiveness of the actions focused on overcoming the fear of speaking depends, however, on whether all people from the environment of the child at home and at school fully understand the nature of SM.13 Because of the fact that the symptoms of SM are

8 W. Langdon, M. Starr (2019), Collaboration between a speech and language pathologist (SLP) and a marriage and family therapist (MFT) in treating selective mutism: a case study report, Listy klinické logopedie, 3(1), pp. 83-86.

${ }^{9}$ A.G. Viana, D.C. Beidel, B. Rabian (2009), Selective mutism: A review and integration of the last 15 years, Clinical Psychology Review, 29(1), pp. 57-67.

${ }^{10} \mathrm{~K}$. Kumpulainen (2002), Phenomenology and treatment of selective mutism. Therapy in Practice, 16, pp. 175-180.

11 B. Oerbeck, M. Stein, T. Wentzel-Larsen, O. Langsrud, H. Kristensen (2014), A randomized controlled trial of a home and school-based intervention for selective mutism - defocused communication and behavioural techniques, Child Adol Ment H-Uk, 19(3), pp. 192-198.

12 B. Oerbeck, M. Stein, A. Pripp, H. Kristensen (2015), Selective mutism: follow-up study 1 year after end of treatment, Eur. Child Adolesc. Psychiatr., 24(7), pp. 757-766.

${ }^{13}$ M. Bystrzanowska (2018), Mutyzm wybiórczy. Poradnik dla nauczycieli i specjalistów, Oficyna Wydawnicza “Impuls”,Kraków, p. 65. 
most fully manifested in the environment outside the family, those who are primarily responsible for the therapeutic and educational activities for a child with SM, and for the identification of comorbid conditions are teachers.

It is worth mentioning that full understanding of the specific nature of the disorder, which is SM, is crucial for the progress in the therapy of a child with SM. This should be emphasised also because of the fact that an analysis of the statements of parents, members of the support group of the Polish Selective Mutism Association, active in the on-line space on Facebook, indicates that sometimes teachers and specialists have incorrect beliefs about SM. This is because they express the conviction that failure to speak is a manifestation of oppositional behaviour, rebellion, being stubborn, and willing to manipulate the environment, failing to notice that in fact it is a manifestation of overwhelming social anxiety ${ }^{14,15}$. Such beliefs result in inappropriate therapeutic, educational and didactic practices.

Therefore, in the case of a child showing the symptoms of SM, a multifaceted, individualised plan of therapeutic and educational activities at school, which would include a joint effort of teachers, specialists and parents, is recommended. ${ }^{16}$

14 S. Cohan, D. Chavira (2008), Refining the Classification of Children with Selective Mutism: A Latent Profile Analysis, Journal of Clinical Child \& Adolescent Psychology, 37(4), pp. 770-784

${ }^{15}$ For example: “...After the interview, the comment of the psychiatrist: 1 . Such children do not speak because of interestedness and only honour some people with conversation (...) 3 . Her behaviour is so that everyone pays attention to her, because if she sits in the corner with her head down, she will attract attention of the teacher...") (https://www.facebook.com/groups/mutyzm.wybiorczy, date of access 18.09.2020).

Based on the analysis of the posted comments of the members of the support group of the Polish Selective Mutism Association, active in the on-line space on Facebook, it can be noted that these are marginal cases.

Instead, a tendency of teachers and specialists to report their lack of knowledge in the field of supporting a child with SM and requests for training, support, methodological materials can be observed.

16 S. Dow, B. Sonies, D. Scheib, D. Moss, H. Leonardm (1995), Practical, Guidelines for the Assessment and Treatment of Selective Mutism, Journal of the American Academy of Child \& Adolescent Psychiatry, no. 34(7), pp. 836-846. 


\section{Forms of therapeutic and educational support intended for children affected by SM}

The main goal of therapeutic and educational activities with children affected by SM is to reduce their anxiety levels (getting rid of the fear of speaking) and to restore nonverbal communication as soon as possible. The therapeutic process is quite long (on average it includes 72 hours of therapy, assuming no other disorders are present. However, the effects of therapeutic work in the place where mutism is present are visible after 2 weeks of work - 3 times a week 30 minutes in the institution, and, in addition, therapy with parents at home and outside home). ${ }^{17}$

The therapeutic process is most often organised according to 3 complementary, intertwining therapeutic approaches (behavioural, cognitive, psychodynamic).

One of the options to help children affected by SM is therapeutic intervention according to the assumptions of the psychodynamic approach. It is relatively rarely used. This is because behavioural techniques are used as the first line therapy (these techniques can be used by parents, teachers, specialists). In psychodynamic therapy, conducted only by a specialist - a psychologist, a child is supported to overcome internal limitations, as well as identify and understand their sources. Some therapists, looking for subconscious problems of a child, use psychodynamic therapy techniques (including the analysis of products, e.g. drawings of a child). In the case of children with SM, it may be beneficial to use elements of supportive therapy (elements of counselling, expressing specific views on reality by the therapist, psychoeducation). In the literature, reports on the possibility of using individual play therapy in children can be found. This form of work is conducted by an actively engaged therapist who allows the child to express themselves while playing. It is an extremely time-consuming technique and must include a com-

${ }^{17}$ M. Bystrzanowska (2018), Mutyzm wybiórczy. Poradnik dla nauczycieli i specjalistów, Oficyna Wydawnicza "Impuls", Kraków. 
prehensive analysis of the child's functioning before and during therapy. It is difficult to determine the effectiveness of the psychodynamic approach in the treatment of children with SM, because to date only a few cases where this approach was used have been analysed.18

In Poland, the most frequently conducted interventions, best described in the literature, are those embedded in the behavioural trend. In this study, first of all, techniques derived from the behavioural approach will be discussed, but it should be remembered that therapeutic interactions conducted within this trend are in practice enriched with elements of cognitive interaction techniques. Introduction of the elements of cognitive therapy, according to the principle that cognitive change is the foundation in the process of changing the functioning of an individual ${ }^{19}$, is reasonable in the case of older children.

\section{Behavioural techniques, behavioural techniques with additional parent-child interaction therapy}

Behavioural therapy has its roots in a behavioural trend in psychology known as behaviour analysis. It is the science concerning behaviour, but above all the environmental factors that shape it. Applied behaviour analysis is part of behaviour analysis. The scope of this science is the creation of procedures to model adaptive behaviour. In Polish literature, the term "behavioural therapy" is used to mean all therapeutic techniques that are based on basic learning processes (classical and operant conditioning, imitative learning). Behavioural therapy is considered to be one of the most effective

18 V. Krysanski (2003), A brief review of selective mutism literature, The Journal of Psychology: Interdisciplinary and Applied, 137(1), pp. 29-40.

19 A. Popiel, E. Pragłowska (2009), Psychoterapia poznawczo-behawioralna praktyka oparta na badaniach Empirycznych, Psychiatria w Praktyce Klinicznej, no. 2(3), pp. 146-155. 
forms of therapeutic interaction. ${ }^{20}$ According to the assumptions of behavioural therapy, the failure to speak in certain situations is a learned, undesirable pattern of behaviour. The purpose of the intervention is to extinguish this maladaptive behaviour, activate the desired behaviour and ultimately "generalise and maintain the effects of therapy after its completion". ${ }^{21}$

In order to explain the course of the therapeutic process, embedded in the behavioural concept, it is necessary to understand, how a neutral stimulus can activate a defensive reaction in the form of refraining from speaking (silence, which, according to the theory of behaviourism is shaped by negative reinforcements).

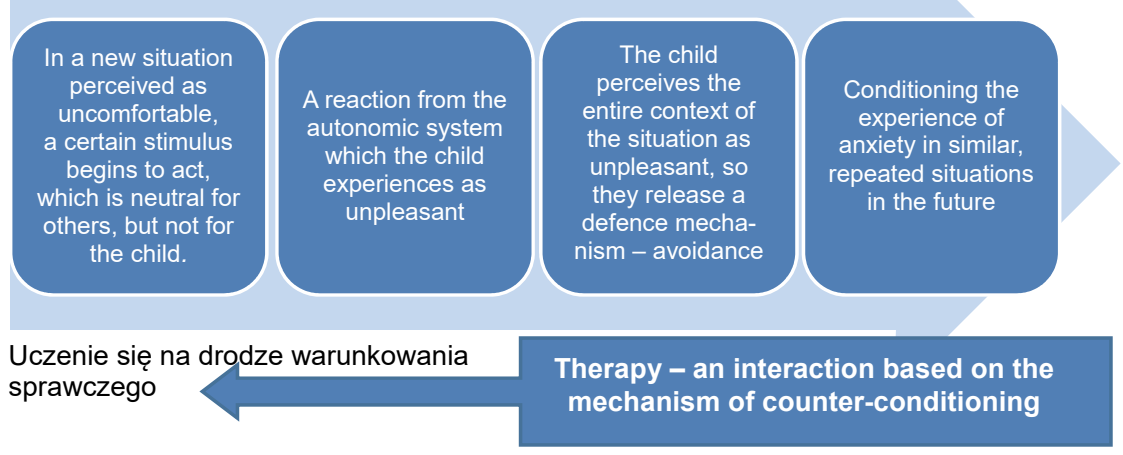

Fig. 1. The process of releasing a defensive reaction, e.g. in the form of refraining from speaking

Source: own elaboration

Based on the analysis of the literature, it can be concluded that techniques based on the behavioural approach and those with additional parent-child interaction therapy effectively alleviate the

20 P. Bąbel, A. Ziółkowska (2014), Terapia behawioralna zaburzeń lękowych, Postępy Psychiatrii i Neurologii, 23, pp. 3-9.

21 P. Bąbel, A. Ziółkowska (2014), Terapia behawioralna zaburzeń lękowych, Postępy Psychiatrii i Neurologii, 23, pp. 3-9. 
symptoms of SM.22,23 According to the family systems theory, it is recognised that many children with SM experience "neurotic" relationships with their parents, who unconsciously develop in the child dependence on themselves, a belief about risk from the outside world, and show an excessive need to control their child. As a consequence, children of neurotic parents experience anxiety in social situations. So far, it has not been explained what mechanisms influence the success of therapeutic interventions in children with SM. However, it can be suspected, that parental factors (including parenting style, dysfunctional parental behaviour) are important. ${ }^{24}$ It is for this reason that the emphasis in SM therapy is on parent child interaction therapy aimed at modifying relationship patterns in the child's family.

Behavioural therapy is usually a multi-method approach, which should consider the specific nature of the child's functioning in a broader context (it is worth determining, among others, the quality of the child's social interactions, their communication needs, the ability to make friends, the motivation to establish social relationships, the level of inhibition in expressing emotions). For this reason, before the start of the educational and therapeutic interaction, it is necessary to perform a functional analysis, set therapeutic goals, organise time and space, and write a therapy plan.

This is because therapeutic interaction should be based on the skills already acquired by the child and use its potential. Behavioural

22 B. Oerbeck, M. Stein, T. Wentzel-Larsen, O. Langsrud, H. Kristensen (2014), A randomized controlled trial of a home and school-based intervention for selective mutism - defocused communication and behavioural techniques, Child Adol Ment H-Uk, 19(3), pp. 192-198.

${ }^{23}$ C. Pereira, J. Ensink, J.K. Kees, M. Guldener, K. Kan, M. de Jonge, R. Lindauer, E. Utens (2020), Effectiveness of a behavioral treatment protocol for selective mutism in children: Design of a randomized controlled trial, Contemporary Clinical Trials Communications, no. 19, article no. 100644.

24 B. Oerbeck, M. Stein, T. Wentzel-Larsen, O. Langsrud, H. Kristensen (2014), A randomized controlled trial of a home and school-based intervention for selective mutism - defocused communication and behavioural techniques, Child Adol Ment H-Uk, 19(3), pp. 192-198. 
techniques that are used in the therapy of mutism include: positive reinforcement technique, symbolic procedures, problem situation management, self-modelling, response initiation, desensitisation, stimulus extinction, modelling.

The positive reinforcement technique complements other therapeutic activities. It is an effective tool, often used intuitively, shaping specific, desired behaviours, reactions. In the process of educational and therapeutic interaction with a child with SM, it is "rewarding" for verbal activity (of course, it is not only about praising, it should be remembered that excessive praise, excitement of a guardian or a teacher with the child's verbal activity may additionally increase tension). The aforementioned technique corresponds to all symbolic procedures, in the course of which the child receives rewards of symbolic nature (e.g. stickers, stamps, badges, beads), which can subsequently be "exchanged" for specific privileges.

A technique that strengthens the performance of verbal activity by a child with SM is shaping the ability to identify and teaching to cope with a problem situation. A child may use a specific pattern of behaviour, a ready pattern of expression in a situation that is/will be uncomfortable.

Self-modelling is one of the techniques that involves a repeated display to the child specially edited videos (with the child in the lead role) modelling the appropriate behaviour. The child observes a situation in which they receive a specific reward for speaking in front of the group and the teacher using an audible and clear tone. ${ }^{25}$

Another behavioural technique, called response initiation, consists in creating a situation enabling individual conversation between the child and the teacher or the therapist, in the environment in which SM is manifested. The assumption is that two people are left alone, can spend even a whole day together, and the child should speak before going out. This is possible because of the fact that an adult quickly develops a relationship with a child through

${ }^{25}$ M. Bray, T. Kehle, K. Lawless, L. Theodore (2003), The relationship of selfefficacy and depression to stuttering, Am. J. Speech Lang Pathol., 12(4), pp. 425-431. 
non-verbal play, empathy statements, and engaging games. The empathetic attitude, supporting the child, providing encouragement, and clear expression of expectation that the child will say at least one word before leaving are necessary. After any verbal activity, the child is rewarded and can come back home. It is worth mentioning that children, in whom this technique was used, usually start a conversation within one to two hours, rarely more than four hours are needed. ${ }^{26}$

In Polish literature27,28, the best known and best described are three behavioural techniques that allow a child with SM to activate speech which include: desensitisation, stimulus extinction, modelling.

The "sliding-in" method derives from the stream of behavioural therapy. It was developed by Maggie Johnson. ${ }^{29}$ It is an interaction based on a counter-conditioning mechanism. Sliding-in is a method based on the process of desensitisation/gradual acceptance by the child of the anxiety-generating stimulus and, over time, the possibility of speaking. It consists in the gradual, regular exposure of the stimulus, that initially causes anxiety in the child - and a gradual increase in the communication load. In practice, without exerting pressure, circumstances in which the child should be verbally active are created. In other words, the child is accustomed to situations that cause their fear, failure to speak, emotional rigidity, tension, anxiety. The optimal situation is when these activities take place in the educational environment, or in the place where the symptoms of SM appear (initially with the participation of the parents).

26 D. Krohn, S. Weckstein, H. Wright (1992), A Study of the Effectiveness of a Specific Treatment for a case for Elective Mutism, Journal of the American Academy of Child and Adolescent Psychiatry, 31(4), pp. 711-718.

27 J. Bala, M. Cabała, K. Giese-Szczap, A. Kiepiela-Koperek, J. Miękina-Pindur, I. Młynarska, A. Pilch, S. Szczęśniak, K. Szyszka (2017), Mutyzm wybiórczy w praktyce terapeutycznej, Oficyna Wydawnicza “Impuls”, Kraków.

${ }^{28}$ M. Bystrzanowska (2018), Mutyzm wybiórczy. Poradnik dla nauczycieli i specjalistów, Oficyna Wydawnicza “Impuls”, Kraków.

${ }^{29}$ M. Johnson, A. Wintgens (2016), The Selective Mutism Resource Manual, Speechmark, London, United Kingdom. 
It is important to obtain verbal messages as soon as possible (the initial success is to obtain onomatopoeias, phones, then words, phrases, expressions, sentences). Therapy of a child consists of consecutive stages. The first is to create a situation in which the child can talk to a teacher or therapist in an empty room (initially in the presence of the parent). Then the child is asked closed-ended questions, and subsequently open-ended questions (first questions in which the answer requires the use of one element, and with time more and more elements). Next, a situation in which the child should talk to unknown people is created. Arranging a situation, in which it is possible to talk to known people, to whom the child has not spoken is another therapeutic task. Talking to a group of children (1-3) in the kindergarten or school is the next difficult task for the child with SM. Therefore, in the final stage of sliding-in, the child should be let communicate with a small number of peers, which then should be increased in such a way that it is possible to participate in group activities. ${ }^{30}$

It is worth mentioning that the advantage of the method is that it can only be carried out in kindergarten or school. That is, in the environment, in which the problem is most apparent. ${ }^{31}$

In therapy of children with SM, techniques that activate the mechanism of "mutual inhibition" are sometimes effective. The main goal of these techniques is to inhibit anxiety reactions in situations requiring the child to speak and replace them with other behaviours (evoking other reactions after suppressing anxiety, which will occur as a result of the stimulus, that initially caused anxiety).

Another group of techniques derived from behaviourism activates the mechanism, which is present in the process of learning by observation (participatory modelling). Initially, the teacher or the therapist shows the child how to behave in a given situation, and

30 J. Bala, M. Cabała, K. Giese-Szczap, A. Kiepiela-Koperek, J. Miękina-Pindur, I. Młynarska, A. Pilch, S. Szczęśniak, K. Szyszka (2017), Mutyzm wybiórczy w praktyce terapeutycznej, Oficyna Wydawnicza “Impuls”, Kraków, pp. 35-36.

${ }^{31}$ C. Pereira, J. Ensink, J.K. Kees, M. Guldener, K. Kan, M. de Jonge, R. Lindauer, E. Utens (2020), Effectiveness of a behavioral treatment protocol for selective mutism in children: Design of a randomized controlled trial, Contemporary Clinical Trials Communications, no. 19, article no. 100644. 
then helps the child complete the task. Here, elements of "mock" activities with dialogues (initially very short), theatre games, in masks, initially in small peer groups are used. In addition, situations in which the child can complete a task together with a parent, teacher, or therapist (e.g. shopping) are provoked.

Video technology can be used to present a role model. Children speaking fluently in specific contexts are recorded, and then combined with a video of a child with SM as if this child was speaking fluently among unknown people, in kindergarten, or school. Holmbeck and Lavigne found it to be an effective technique for teaching children to communicate, which requires less involvement from therapists. ${ }^{32}$ Blum et al. have also found that this technique may be effective for certain children. They perceive the short duration of recordings and the need for frequent playback in order to achieve the desired effect as a limitation. ${ }^{33}$

To sum up, it should be emphasised that techniques derived from the behavioural approach are effective in the therapy of the symptoms of SM. In the case of children older than 12 years of age, additional cognitive elements, which are used in traditional cognitive behavioural anxiety therapy, can also be optionally introduced. ${ }^{34}$

Family therapy is another option of interaction that can complement the use of behavioural techniques. It seems to be particularly important as family factors play a role in the potential development and consolidation of selective mutism (these factors were mentioned earlier in this study). The effectiveness of family therapy in reducing the symptoms of SM has not been empirically confirmed, yet including the family in the therapeutic process may play an important role. Cooperation, support, and empathetic attitude of

${ }^{32}$ G. Holmbeck, J. Lavigne (1992), Combining self-modeling and stimulus fading in the treatment of an electively mute child, Psychotherapy: Theory, Research, Practice, Training, 29(4), pp. 661-667.

${ }^{33}$ N. Blum, R. Kell, H. Starr, W. Lender, K. Bradley-Klug, M. Osborne, P. Dowrick (1998), Case Study: Audio Feedforward Treatment of Selective Mutism, Journal of the American Academy of Child and Adolescent Psychiatry, 37(1), pp. 40-43.

${ }^{34}$ R. Bergman (2013), Treatment for Children with Selective Mutism: An Integrative Behavioral Approach, Oxford University Press, USA. 
parents and siblings helps the child to reduce the level of tension and overcome anxiety in social situations. ${ }^{35}$

One of the behavioural approaches to SM therapy is a specific type of family therapy, abbreviated as PCIT-SM (Parent-Child Interaction Therapy in SM). It is a program created in 2009 (and so far successfully used) by S. Kurtz. PCIT is considered the gold standard in the treatment of SM, especially in the youngest children. The foundation of therapy is the intention to teach parents to be a therapist for their child. Parents are taught new behaviours to help their child learn to talk to others. ${ }^{36}$ PCIT-SM seems to be an effective method in the therapy of children with SM aged from 4 to 10.37

To sum up, few scientific publications report research that covered the issue of the effectiveness of therapeutic interventions in SM and comorbid disorders. These reported, cited in this study, indicate the effectiveness of behavioural strategies. It is worth mentioning, however, that the multi-method approach, combining cognitive and behavioural strategies, can be rewarding. In 2016, Elisa ShiponBlum analysed the results of the multi-method approach in a pilot study (the use of psychoeducation, techniques of gradual exposure to a stimulus causing anxiety, involvement of parents in the therapy as early as at the first therapeutic session). The author of the study indicated the effectiveness of this type of interaction on children aged 6 who participated on average 9 weeks in the therapy conducted by one therapist specialised in SM therapy. ${ }^{38,39}$

35 K. Kumpulainen (2002), Phenomenology and treatment of selective mutism. Therapy in Practice, 16, pp. 175-180.

36 S. Kurtz, (2019), What is Selective Mutism?, (https://www.kurtzpsychology. com/selective-mutism/what-is-selective-mutism/, date of access: 21.09.20202).

${ }^{37}$ R. Catchpole, R. Young, S. Baer, T. Salih (2019), Examining a novel, parent child interaction therapy-informed, behavioral treatment of selective mutism, Journal of Anxiety Disorders, no. 66, article no: 102112.

38 S. Cohan, D. Chavira (2008), Refining the Classification of Children with Selective Mutism: A Latent Profile Analysis, Journal of Clinical Child \& Adolescent Psychology, 37(4), pp. 770-784.

39 P. Muris, T. Ollendick (2015), Children Who are Anxious in Silence: A Review on Selective Mutism, the New Anxiety Disorder in DSM-5. Clin Child Fam Psychol Rev., 18(2), pp. 151-169. 


\section{Conclusion}

Selective mutism is one of the childhood disorders. This is a peculiar, still not fully recognised problem that is of multidimensional nature. This results in various approaches to therapeutic management, as well as the aetiology of SM. Because of the fact that it is a relatively rare disorder in the population, research on SM constitutes a challenge, and most of the obtained empirical data come from small groups, descriptions of few cases.

In light of the above, the fact that theoretical and empirical studies that increase awareness of SM as a childhood disorder, which makes life of preschool and school children and their families difficult, have been conducted recently, is optimistic. However, considering the multidimensional impact of this disorder on the social functioning of an individual, further research to address the effectiveness of specific therapeutic approaches is needed. Nevertheless, it should be remembered that for planning educational and therapeutic activities for a child with SM, it is necessary to create an individual plan (including techniques from various therapeutic approaches), which will be adequate to the needs and level of functioning of a given child. It is also worth emphasising the need for the strongest impact in the environment, where mutism is present - therefore in the educational environment.

\section{References}

Bawolska A. (2019), Dziecko z mutyzmem wybiórczym - charakterystyka zjawiska oraz sposoby przeciwdziałania trudnościom. Niepełnosprawność - Dyskursy Pedagogiki Specjalnej, (33), pp. 204-212.

Bala J., Cabała M., Giese-Szczap K., Kiepiela-Koperek A., Miękina-Pindur J., Młynarska I., Pilch A., Szczęśniak S., Szyszka K. (2017), Mutyzm wybiórczy w praktyce terapeutycznej, Impuls, Kraków.

Bąbel P., Ziółkowska A. (2014), Terapia behawioralna zaburzeń lękowych, Postępy Psychiatrii i Neurologii, 23, pp. 3-9.

Bergman R. (2013), Treatment for Children with Selective Mutism: An Integrative Behavioral Approach, Oxford University Press, USA. 
Blum N., Kell R., Starr H., Lender W., Bradley-Klug K., Osborne M., Dowrick P. (1998), Case Study: Audio Feedforward Treatment of Selective Mutism, Journal of the American Academy of Child and Adolescent Psychiatry, 37(1), pp. 40-43.

Bray M., Kehle T., Lawless K., Theodore L. (2003), The relationship of self-efficacy and depression to stuttering, Am J Speech Lang Pathol., 12(4), pp. 425-431.

Bystrzanowska M. (2018), Mutyzm wybiórczy. Poradnik dla nauczycieli i specjalistów, Impuls, Kraków.

Catchpole R., Young R., Baer S., Salih T. (2019), Examining a novel, parent child interaction therapy-informed, behavioral treatment of selective mutism, Journal of Anxiety Disorders, no. 66, article no: 102112.

Cohan S., Chavira D. (2008), Refining the Classification of Children with Selective Mutism: A Latent Profile Analysis, Journal of Clinical Child \& Adolescent Psychology, 37(4), pp. 770-784.

Dow S., Sonies B., Scheib D., Moss D., Leonardm H. (1995), Practical, Guidelines for the Assessment and Treatment of Selective Mutism, Journal of the American Academy of Child \& Adolescent Psychiatry, no. 34(7), pp. 836-846.

DSM-V, Diagnostic and Statistical Manual of Mental Disorders, $5^{\text {th }}$ ed., American Psychiatric Association, 2013.

Holka-Pokorska J., Piróg-Balcerzak A., Jarema M. (2018), The controversy around the diagnosis of selective mutism - a critical analysis of three cases in the light of modern research and diagnostic criteria, Psychiatria Polska, 52(2), pp. 323-343

Holmbeck G., Lavigne J. (1992), Combining self-modeling and stimulus fading in the treatment of an electively mute child, Psychotherapy: Theory, Research, Practice, Training, 29(4), pp. 661-667.

International Statistical Classification of Diseases and Related Health Problems, ICD-10, Volume I, 2008.

Johnson M., Wintgens A. (2016), The Selective Mutism Resource Manual, Speechmark, London, United Kingdom.

Krohn D., Weckstein S., Wright H. (1992), A Study of the Effectiveness of a Specific Treatment for a case for Elective Mutism, Journal of the American Academy of Child and Adolescent Psychiatry, 31(4), pp. 711-718.

Kumpulainen K. (2002), Phenomenology and treatment of selective mutism. Therapy in Practice, 16, pp. 175-180.

Kurtz S., (2019), What is Selective Mutism?, (https://www.kurtzpsychology.com/ selective-mutism/what-is-selective-mutism/, date of access: 21.09.20202).

Langdon W., Starr M. (2019), Collaboration between a speech and language pathologist (SLP) and a marriage and family therapist (MFT) in treating selective mutism: a case study report, Listy klinické logopedie, 3(1), pp. 83-86.

Krysanski V. (2003), A brief review of selective mutism literature, The Journal of Psychology: Interdisciplinary and Applied, 137(1), pp. 29-40. 
Muris P., Ollendick T. (2015), Children Who are Anxious in Silence: A Review on Selective Mutism, the New Anxiety Disorder in DSM-5. Clin Child Fam Psychol Rev., 18(2), pp. 151-169.

Oerbeck B., Stein M., Wentzel-Larsen T., Langsrud O., Kristensen H. (2014), A randomized controlled trial of a home and school-based intervention for selective mutism - defocused communication and behavioural techniques, Child Adol Ment H-Uk, 19(3), pp. 192-198.

Oerbeck B., Stein M., Pripp A., Kristensen H. (2015), Selective mutism: follow-up study 1 year after end of treatment, Eur. Child Adolesc. Psychiatr., 24(7), pp. 757-766.

Pereira C., Ensink J, Kees, Guldener M., Kan K., de Jonge M., Lindauer R., Utens E. (2020), Effectiveness of a behavioral treatment protocol for selective mutism in children: Design of a randomized controlled trial, Contemporary Clinical Trials Communications, no. 19, article no. 100644.

Popiel A., Pragłowska E. (2009), Psychoterapia poznawczo-behawioralna - praktyka oparta na badaniach empirycznych, Psychiatria w Praktyce Klinicznej, no. 2(3), pp. 146-155.

Rozenek E., Orlof W., Nowicka Z. (2020), Mutyzm wybiórczy-opis zaburzenia i etiologia: czy wybiórczy brak mowy jest zaledwie wierzchołkiem góry lodowej?, Psychiatria Polska, 54(2), pp. 333-349.

Sharp W., Sherman C., Alan M. (2007), Selective Mutism and Anxiety: A review of the current conceptualization of the disorder, Journal of Anxiety Disorders, 21, pp. 568-579.

Stone B., Kratochwill T., Sladezcek I., Serlin R. (2002), Treatment of selective mutism: A best-evidence synthesis. School Psychology Quarterly, 17(2), p. 168-190.

Wong P. (2010), Selective Mutism: A Review of Etiology, Comorbidities, and Treatment, Psychiatry, 7(3), pp. 23-31.

Viana AG, Beidel DC, Rabian B (2009), Selective mutism: A review and integration of the last 15 years, Clinical Psychology Review, 29(1), pp. 57-67. 